FACTA UNIVERSITATIS

Series: Economics and Organization Vol. 15, No 4, 2018, pp. 331 - 348

https://doi.org/10.22190/FUEO1804331S

Original Scientific Paper

\begin{abstract}
MARKETING CULTURE IN FINANCIAL SERVICES WITH SPECIFIC REFERENCE TO RETAIL BANKING IN INDIA
\end{abstract}

\author{
UDC 658.8:336(540)
}

\title{
Ravi Shanker
}

Indian Institute of Foreign Trade, New Delhi, India

\begin{abstract}
Service industry is fast becoming the key to a nation's success and its importance in the world economy is tremendous. In India too, the service industry boom has powered the growth of the economy. Service industry is different and hence poses special management challenges. There are some unusual variables that affect the performance of these organizations. The 'marketing culture' of the organization is one such factor. The paper relates to it in the context of the banking sector in India. Post liberalization, the banking industry became highly competitive as the number of banking institutions increased multifold. Currently there are 87 banks in India $(21$ public sector banks, 21 private sector banks, and 45 foreign financial intermediaries and Banks) competing with each other. It has also been observed that one of the variables on the basis of which the banks compete is providing superior customer contacts, which is possible through customer centric employees and the marketing culture that exist in the banking organization. Marketing culture refers to the pattern of shared values and beliefs that help individuals understand the marketing function and provide them with norms for behavior in the firm. The orientation and culture towards marketing within the organization is the highest imperative.

The paper is based on primary research being undertaken on three banks selected from each category mentioned above. A questionnaire was developed with the help of which the marketing culture of a service firm was assessed. The questionnaire uses 34 items measuring six dimensions of marketing culture, as identified by leading researchers. These six dimensions are service quality, internal communication, innovativeness, organization, inter-personal relationships and selling tasks. The paper has used parametric approach to analyze and understand the attitude of the employees of each of the banks towards the dimensions identified. The inter-relationships among the six dimensions for each of the banks have also been studied. Weights have been assigned to the six dimensions and the responses have been assessed accordingly. The results of
\end{abstract}

Received July 27, 2018 / Accepted September 7, 2018

Corresponding author: Ravi Shanker

Indian Institute of Foreign Trade, IIFT Bhawan B-21, Qutab Institutional Area, New Delhi - 110 016, India

E-mail: profravishanker@gmail.com 
the analysis clearly show the foreign banks score the highest on the IMC index and the nationalized banks the lowest.

Key words: marketing culture, service quality, internal communication, innovativeness, inter-personal relationships and selling tasks

JEL Classification: M31, G21

\section{INTRODUCTION}

The review of classical marketing concepts to contemporary marketing theories clarifies the misunderstandings regarding marketing. The confusion about marketing gets complex if you look at the variety of definitions of marketing where each one relates to a limited scope of marketing and gives a holistic view of complete marketing function. Marketing has a deep rooted meaning which goes beyond the 4 Ps, advertising and selling products. In essence, marketing is a way of organizing the activities of the enterprise that includes the tools and techniques for identifying, anticipating and satisfying customer requirements, maintaining marketing orientation and organizational culture etc. Therefore, in this chapter an attempt is made to segregate the selected definitions of marketing so as to arrive at a clearer understanding of marketing which will be useful as the background to explore the status and relevance of the marketing culture in the service sector.

\section{UNDERSTANDING MARKETING}

\subsection{Marketing as a process}

Marketing as a phenomenon can be looked upon through various approaches. Marketing has been described differently as, a philosophy, an orientation and a whole set of culture. In the academic establishment in 1985, the American Marketing Association (AMA) redefined marketing as "the process of planning and executing the conception, pricing, promotion and distribution of ideas, goods and services to create exchange and satisfy individual and organizational activities." (Lusch, 2007, p. 264). This definition suggests that the marketing process relates to planning and executing the conception, pricing, distribution and promotion of goods, services and ideas but the scope of marketing is restricted to 4Ps. Recognizing the shifts, the American Marketing Association (2004) redefined marketing as an organizational function and a set of processes for creating, communicating and delivering value to customers and for managing customer relationships in ways that benefit the organization and its stakeholders (Gundlach, 2007). And as approved by the same association in 2013, "Marketing is the activity, set of institutions, and processes for creating, communicating, delivering, and exchanging offerings that have value for customers, clients, partners and society at large" (AMA, 2013). The latter definition is the modernization of the previous one which does not take into consideration what the customer would want marketing to be. 


\subsection{Marketing as a philosophy}

The marketing concept as an essential philosophy directing marketing in practice still prevails. M.J. Baker introduced marketing as a business philosophy. According to Baker (1974), marketing requires the firm to do what it has always set out to do - combine the resources at its disposal in the manner which will enable it to achieve its long run profit goals. This definition suggests that marketing is not an activity but it is a cognitive way of thinking or a state of mind of doing business and a firm should base all its activities on the needs and wants of customers in the selected target segments or markets.

In order to fully operationalize the marketing philosophy of business, Anderson suggested that 'marketing' must negotiate with top management and the other functional areas to implement its strategies. This coalition perspective suggests that marketing must take an active role in promoting its strategic options by demonstrating the survival value of the consumer orientation to other internal coalitions to have coordinated approaches for making the most effective use of the resources and the budgets. Kotler (2003) identified six alternative philosophies for an organization to conduct business according to their orientation about going to marketplace and doing marketing activities, which are production concept, product concept, selling concept, marketing concept, societal marketing concept which states that the philosophy is that an organization must determine the needs and wants of the target markets and create, communicate and deliver more effectively and efficiently in a way that maintains and improves the well-being of the society and the consumers in that society. To express such a concept or philosophy, Paul Mazur (1947) defined marketing as "the delivery of a standard of living" and Total Marketing which is a recent buzzword combining customer orientation, relationship marketing, CRM etc.

This itself is or may lead to a market-oriented view where an organization's activities are geared to the processes of product, technology and production which already exist and it is entirely different from the production concept (Grönroos, 1989).

\subsection{Marketing as an orientation}

Kotler (2003) has also described numerous changes in the business orientation over time. While a strong association between marketing orientation development and company performance has been established, the understanding of the marketing orientation remains unclear since some studies have suggested a philosophical nature for marketing orientation and other studies have concluded that marketing orientation represents a behavioral notion. Exploitation of only a very few companies can ascertain the indulgence in the implication of marketing orientation whereas a big chunk of mainstream companies normally fail to create and make use of the marketing orientation concept (Hooley et al., 1990). "Market orientation" (or market-oriented behavior) is a popular term used by marketing practitioners as an indicator of the extent to which an organization implements the "marketing concept" (Jaworski \& Kohli, 1993). Gronroos (1989, pp. 52-60) proposed his definition of marketing according to the customer's view of the marketing function, and suggested that marketing is to establish develop and commercialize long-term customer relationships, so that the objectives of the parties involved are met. This is done by mutual exchange and keeping in mind the needs of customers. Thus, marketing as an orientation focuses on the customer orientation and planning which has the customer at the focal point and each department of any organization shall work for. 


\section{THE MARKETING CULTURE}

The construct of market orientation is believed to be a result of the implementation of the marketing concept (Kohli \& Jaworski, 1990; Narver \& Slater, 1990). Sometimes the behavioural point of view (Kirca et al., 2005) and cultural perspective, the other times, (Homburg \& Pflesser, 2000) are reflected with regard to this. Although some studies considered market orientation as a facet of organizational culture (Homburg \& Pflesser, 2000), or as a culture within the firm (Deshpande \& Webster, 1989; Narver and Slater, 1990), some researchers observed it as an altogether different construct (Farley et al., 2008). Strategic development of a customer orientation within firms is one of the growing concerns interrogating its linkage with organizational culture. Thus, in the past few years, a few researchers have begun an analysis of the relationship between the culture of organization and the marketing of services (Parasuraman, 1987) giving rise to the concept of marketing culture.

Scholars have begun to recognize the importance of organizational culture in the management of the marketing function. Growing concern for issues of implementation in marketing strategy and the development of a customer orientation within organizations is also raising questions specifically to the organizational culture. When behavioural actions of organisational members unite, it forms a culture in the workplace (Gregory, 1983). Marketing culture provides unwritten policies and guidelines to employees and behavioral norms for conduct within an organization and portray the same in its interaction with the other parties viz. customers, government, etc. It constitutes that part of a firm's overall culture which refers to the pattern of shared values and beliefs to help employees understand and "feel" the marketing function and consequently execute efficient marketing activities. The validation of certain "do's and don'ts" can be done on the grounds of an established culture (Harrison, 1972). In other words, the marketing culture of a service firm refers to the way marketing "things" are being undertaken by the service employees. There are enough examples where we can compare the marketing culture of a Government sector hospital and a private sector hospital, or airlines or a bank.

\subsection{Internal marketing culture as a part of organizational culture}

Despite of the thin empirical literature of culture, the same is conceptualized by various studies (Beyer \& Trite, 1987; Kilmann \& Saxton, 1983; Thompson \& Wildavsky, 1986). Lately, the academicians and marketers have been paying huge attention to the significance of a firm's marketing culture (Parasuraman, 1987; Schneider \& Bowen, 1985). Many popular scholarly studies like Deal \& Kennedy, 1982; Peters \& Waterman, 1982; Schein, 1985 contain researches related to the construct of culture, or more specifically, organization culture in the years gone by.

It was in the year 1976 that the concept of Internal Marketing culture was first proposed as a necessity and a pre-requisite for providing satisfactory and high quality services by Berry et al. (1976); Berry, 1984. Since 1980, the study of organizational culture is considered to be "one of the most fascinating and yet elusive topics for management researchers" (Harris \& Ogbonna, 2002, p. 31). O'Reilly (1989) is of the opinion that when employees' expectations and customers' requirement fit well in an organization, there exists an organizational culture. It has been defined as "the pattern of shared values and beliefs that help individuals understand organizational functioning and thus provide them with norms for behaviour in the organization" (Deshpande \& Webster, 1989, p. 4). Thus organizational culture focuses attention on informal, 
hidden forces within a firm - forces that exert tremendous influence on the behavior and productivity of its employees, perhaps more so than formal, written policies or guidelines.

Webster (1993) has recently described marketing culture as a comprehensive construct made up of varied facets which involves the significance of service quality, interpersonal relationships, the selling task, organization, internal communications, and innovativeness. Thus, marketing culture is one that concentrates on implementing the most recent innovations relevant to that particular industry. Yet, another might focus on the continuous monitoring and improving of the quality of established practices. Implication of a strong marketing culture and the decision regarding establishment of its extent (i.e. to upgrade service quality, to innovate, etc.) should be evaluated on the basis of various factors like probable return.

\subsection{Corporate culture and organizational performance}

This has been understood that human element has a significant influence on the successful execution of marketing plans, since their formulation and implementation depend on individuals in the firm. So there exists something which is helpful in attaining a better performance for an organization that is referred to as organizational culture. Marketing as organizational culture emphasizes the understanding of the values and beliefs of the employees and developing a marketing culture, which creates the behavior of employees providing superior value to the customers and enables attaining excellent business performance. Culture is the significant solution when it comes to the decision of strategic direction of firms (Smircich, 1983). A new challenge to service marketers is cultivating and sustaining a service culture which correlates marketing culture and successful marketing of services positively (Berry, L.L. et al., 1989). Many researchers have attempted to find a connection between the adoption rate of marketing orientation and company performance (e.g. Narver \& Slater, 1990; Cadogan \& Diamantopoulos, 1995; Anttila et al., 1995) but the understanding of marketing orientation is still not clear.

The concept of marketing effectiveness has also been extensively discussed because of its strong association with many valuable organizational outcomes, such as stable, long-term growth, enhanced customer satisfaction, a competitive advantage, and a strong marketing orientation (Kotler, 1977; Norborn et al., 1990). The corporate literature indicates positive linkage between market orientation and performance of service delivered (Jaworski \& Kohli, 1993, p. 96; Slater \& Narver, 1994, p. 95; 2000). As the external and social environment is crucial to the working of a firm, culture also has a direct impact on its productivity (Schneider $\&$ Reichers, 1983).

Thus, the underlying principle behind studying marketing culture and orientation is that it can affect the commitment and performance of an organization (Lok \& Crawford, 2004). This industry-specific research attempts to assess and measure the marketing culture within the retail banking industry in India, and to provide top management of these banks with the suggestions which may be required for improving the banks' selling effectiveness with proper marketing orientation. The reasons for choosing this sector and the three banks in particular have been discussed in detail in the report. The paper further gives an elaborative literature on the marketing culture in the banking sector. 


\section{Marketing CUlture in Service SeCtor}

Due to the unique and 'handle with care' characteristics of services (i.e. intangibility, inseparability of production and consumption, perishability, and variability), the nature of the culture of a service firm is particularly significant requiring specific attention for better performance (Webster, 1995). Thus, marketing is not only a part of some dedicated department for the marketing activities, but rather staff and support functions are an elementary part of it. In most of the organizations, employees have something to do with marketing especially when they come in direct contact with the representatives of customers (Gummesson, 1987) like in the banking sector.

\subsection{Banking sector evolution in India}

The banking history in India has undergone a long journey and also achieved a new stature with the dynamic timeframe where banking practices have shifted from traditional Britishers' era to the reforms period, nationalization to privatization of banks and the arrival of foreign banks to India.

Post the recent set of reforms such as demonetization, various industries in India, especially the banking industry, are ripe with challenges and changes. One of the major challenges that the Indian banking industry has been facing is minimizing the inconvenience caused to the end customers. The role of the employees in banking services is considered very crucial for production as well as delivery of the service. Generally, these services are made and sold at the same time, where customers also participate simultaneously in the process. Another reason explaining the significant role of employees is that the services of banks are of standardized nature through which customers can get basic services from all banks (O'Reilly, 2003). Customers' needs are ever changing, they demand higher level of services. Here lies the competition and the marketing culture can be used as a differentiating tool. That is the reason banks are changing their ways of dealing with their clients from a transaction focus to a relationship focus strategy with the aim of long-term customer retention through more enduring relationships. This requires employees who are highly qualified, motivated, and empowered (Zeithaml et al., 2006).

Effective interactions between employees and customers mean that both parties have a strong impact on the service performance (Luk, 1997). Service quality is implicitly considered as a component of the interactions between employee-customer (Parasuraman et al., 1988). This trait must be incorporated in the sales culture of the banks. The reports of National Skill Development Corporation of India and the McKinsey and Company (2010) exhibit the importance of human resources as the important success factor for Indian banks (Maji \& Hazarika, 2016).

The Indian banking industry has changed dramatically over the years. A huge growth in savings due to the rising income levels is a major factor affecting the banking sector. The access to banking services has also improved over time due to untiring government efforts to encourage technology in banking and increase expansion in unbanked and non-metropolitan regions. In recent years, the Indian banking industry has witnessed the introduction of innovative banking models like payments and small finance banks. The digital payments system in India has evolved the most with India's Immediate Payment Service (IMPS) being the only system at level 5 in the Faster Payments Innovation Index (FPII). 


\subsection{Competition in Indian banks}

Throughout the world, the banking industry is going through the fast paced environment where banks have to be competitive and resourceful for their very existence (Devlin \& Ennew, 1997). As the savings of society are taken care of by the banking sector, it is predominantly significant to have competition amongst banks. Also, banking competition aids the growth of national economy by managing cost inefficiencies and welfare gains (Jayaratne \& Strahan, 1996). Regulatory Authorities encourage banking competition, and central banks take necessary actions to enhance the economic conditions of nation by altering competitive levels time to time (Kapsis, 2012). Also, such competition leads to a reduction in operating costs and, hence, eradicating inefficiencies in the banking industry.

With the outset of the banking sector reforms in India post 1991, the relationship between competition and efficiency in the Indian banking sector is crucial as well as feasible to investigate in Indian markets (Arrawatia et al., 2015). Literature draws attention towards the increased competition in the banking sector during the last decade (Arrawatia \& Misra, 2012, Maji \& Hazarika, 2018). The advent of banking reforms represented Indian banks, especially public sector banks (PSBs), to the rigorous domestic and international competition. In the fierce competitive environment, the survival of Indian banks particularly PSBs has become critical because only the efficient banks with favorable culture can withstand the external forces and maintain decent market share (Kumar \& Gulati, 2008).

\subsection{Current position of public sector banks}

The three segments of banks' ownership in India viz. public sector banks, private sector banks, and foreign banks have diversified cultures, regulations, operating conditions.

PSBs in India have a vast spread country-wide accounting for almost 80 per cent of the total banking business share (CAFRAL, 2014). Their role in India's economic and social development is massive and well accepted. They have strong presence at rural and semi-urban areas and provide employment at large scale. In contrast, private sector banks are less laborintensive with limited number of branches. But adoption of modern technology and the customer-oriented approach make them more profitable. On the other hand, foreign banks are equipped with even better technology, and risk management skills limiting their operations in major urban centers (Kumar \& Gulati, 2008). All this has changed the competitive landscape and banking practices of the Indian banking sector ultimately declining the market share of PSBs in terms of total assets, investments, advances, deposits of the Indian banking industry (Mohan et.al, 2005; Mohan, 2005).

In spite of the whole scenario, PSBs still act as catalysts for socio-economic growth in the country which makes them dominating players in the Indian banking sector, although their market share has decreased in the deregulatory establishment making policy makers concerned about the retention of their position.

\subsection{Perception of banks}

A survey was carried out by Rediffusion Y\&R in 2014 where a sample of 4000 chief wage earners was taken. The Survey was aimed at the perceptions the chief wage earners had about the three categories of banking institutions which helped in their positioning. 
The survey did not cover Co-operative and rural banks. The findings were quite revealing as there were very clear demarcations. The public sector banks were considered as rich in heritage, authentic, traditional and socially responsible. Private sector banks were seen as chic, stylish, trendy, customer-centric and more approachable. Other multi-national foreign banks were perceived as high performance, up-to-date, progressive and caring more for money than for customers.

\section{RESEARCH OBJECTIVES}

This paper aims to provide insight into the marketing culture in the Indian banking industry with reference to internal marketing across the private sector, public sector and foreign banks. It intends to identify the various constituents, dimensions and parameters of Internal marketing in services sector organizations. This paper further intends to give suggestions for improvement of marketing culture in the banks.

\section{MeTHODOLOGY}

\subsection{Research settings}

Retail banking industry in India has been selected for the purpose of the research. Following the recent set of reforms such as demonetization, various industries in India, especially the banking industry are ripe with challenges and changes. The role of marketing in financial services industry in general and retail banking in particular is immense and growing and hence an orientation and culture towards marketing within the organization is the highest imperative. With 87 banks competing in a relatively limited and almost saturated market, commercial banks' competitiveness is based on their abilities to provide customers with high quality of service. Thus, banks have to build a strong sales culture among their employees and improve the quality of their services including customer services. Within the industry three kinds of banks have been chosen using the convenience sampling viz. foreign banks operating in India, Indian private banks and Indian public sector banks.

The three banks selected belong to different categories of the industry having different set of customer profiles and success patterns in the past. Commercial banks in India have a vital role in the socio-economic development process.

\subsection{Sample design}

A sample of 150 employees and managers was involved in the survey. A structured and self-administered survey in the form of a detailed questionnaire was used, targeting managers and employees of the chosen banks operating in India to assess their marketing culture. A parametric approach was applied on the responses and the data set was checked with normality and descriptive data analysis. The Marketing Culture Index was devised using the Weighted Average Method. 


\subsection{Measurement scales}

The majority of scales used to measure the constructs were drawn from Karatepe et al. (2005) in the field with fewer adaptations to a financial organizational context.

\section{ANALYSIS AND INTERPRETATION}

\subsection{Marketing culture assessment}

A leading researcher has designed a paradigm for developing measures of marketing constructs. A questionnaire has been developed with the help of which the marketing culture of a service firm can be assessed. This questionnaire makes use of 34 items measuring six dimensions of marketing culture, as identified by leading researchers. The six dimensions used to assess the marketing culture of service firms are:

- Service Quality: This shall involve the assessment of exceptional service; commitment of top management to providing quality service; systematic, regular measurement and monitoring of employees' performance; employees' focus on customer needs, desires and attitudes; the belief of the employees that their behavior reflects the firm's; the ability of the employees to meet the firm's expectations; employee's communication skills; employees' attention to detail in their work.

- Internal Communication: This shall involve the assessment of the firm having an approved set of policies and procedures which is made available to every employee; that supervisors clearly state their expectations; that each employee understands the mission and general objectives of the firm; the encouragement of front-line service personnel to become involved in standard setting; the firm focusing efforts on training and motivating employees.

- Innovativeness: This shall involve the assessment of the employees to be receptive to ideas for change; the firm keeping up with technological advances; the receptiveness of the company to change.

- Organization: This shall involve the assessment of each employee to be well organized; for careful planning to be each employee's daily routine; for employees to prioritize work; for employees' work area to be well organized; each employee to manage time well.

- Interpersonal Relationships: This shall involve the assessment of the company to be considerate of employee's feelings; for the firm to treat each employee as an important part of the organization; for employees to feel comfortable in giving opinions to higher management; that managers/supervisors have an "open-door" policy; management's interaction with front-line employees.

- Selling Task: This shall involve the assessment of the firm's emphasis on hiring the right people; the firm providing skill-based training and product knowledge to frontline service providers; the encouragement of creative approaches to selling; the firm's recognition of high achievers in selling; employees to enjoy pursuing new accounts; the firm to reward employees; better than competing firms, with incentives to sell; employees to aggressively pursue new business.

For assessing each of these six dimensions there are some questions, which need to be probed. The response to these questions in the questionnaire is recorded on a six-point scale, 
consisting of the options: Necessary (6), Very Important (5), Important (4), Somewhat Important (3), Of Little Importance (2), No Importance (1).

This six point scale relates either to the importance of the item or the extent to which the firm possesses that attribute. 150 employees of the three banks (50 employees of each of the three banks) were asked to respond to the above questionnaire.

\subsubsection{Analysis of marketing culture}

It is very important to analyze which aspects of Marketing Culture are particularly strong in a bank and which aspects need specific improvement. 6 dimensions have been used to assess the culture of a bank. Each of these 6 dimensions is measured by some variables the number of which varies.

Table 1 Number of variables under each dimensions of marketing culture

\begin{tabular}{lc}
\hline Dimension & No. of variables \\
\hline I Service Quality & 8 \\
II Internal Communication & 6 \\
III Innovativeness & 3 \\
IV Organization & 5 \\
V Interpersonal Relationships & 5 \\
VI Selling Task & 7 \\
TOTAL & 34 \\
\hline
\end{tabular}

Source: Osman M. Karatepe et al. (2005)

\subsubsection{Comparison among banks}

The responses to the questionnaire were measured on a scale of 1 to 6 ranging from 'not important' to 'necessary'. The score for each variable under a particular dimension was added to get the total for each dimension for each respondent. These figures were then added to get the total score by all respondents for each of the 6 dimensions. The total score for each dimension was then divided by the number of respondents to arrive at the average score for each dimension. This average score cannot be used for inter-dimension comparison in a bank (because of the different number of variables used to assess each dimension), but can definitely be used to compare the banks with respect to each dimension.

Table 2 Comparison on marketing culture variable of three categories of banks

\begin{tabular}{lccc}
\hline & Foreign banks & Private sector banks & Public sector banks \\
\hline Service quality & 36.76 & 28.60 & 17.80 \\
Internal communication & 28.80 & 20.20 & 15.88 \\
Innovativeness & 22.36 & 13.12 & 8.52 \\
Organization & 26.28 & 17.12 & 14.48 \\
Interpersonal relationships & 26.32 & 15.48 & 16.96 \\
Selling task & 31.28 & 23.04 & 20.00 \\
\hline
\end{tabular}




\subsubsection{Comparison among dimensions}

The average scores and their method of calculation have been mentioned clearly in the paragraph above. Subsequently, these average scores were divided by the number of variables that were used to assess the respective dimensions (mentioned at the beginning of this chapter). This brings out the figure for 'average score per variable' for each of the dimensions. These figures can be used to compare each dimension within a bank. The process has been repeated for all the banks separately.

Table 3 Average score of foreign banks on six variables

\begin{tabular}{lcc}
\hline & Average score per variable & RANK \\
\hline Service quality & 4.595 & V \\
Internal communication & 4.800 & IV \\
Innovativeness & 5.453 & I \\
Organization & 5.256 & III \\
Interpersonal relationships & 5.264 & II \\
Selling task & 4.469 & VI \\
\hline
\end{tabular}

Table 4 Average score of private banks on six variables

\begin{tabular}{lcc}
\hline & Average score per variable & RANK \\
\hline Service quality & 3.575 & II \\
Internal communication & 3.367 & IV \\
Innovativeness & 4.373 & I \\
Organization & 3.424 & III \\
Interpersonal relationships & 3.096 & VI \\
Selling task & 3.291 & V \\
\hline
\end{tabular}

Table 5 Average score of public sector banks on six variables

\begin{tabular}{lcc}
\hline & Average score per variable & RANK \\
\hline Service quality & 2.225 & VI \\
Internal communication & 2.647 & V \\
Innovativeness & 2.840 & IV \\
Organization & 2.896 & II \\
Interpersonal relationships & 3.392 & I \\
Selling task & 2.857 & III \\
\hline
\end{tabular}

\subsection{Marketing culture assessment}

The marketing cultures of private sector banks and public sector banks have been assessed through the analysis of data collected through the questionnaire. However, to get a better comparison of the marketing cultures of the two banks, an index has been developed to numerically assess the six dimensions measuring the marketing culture.

The dimensions have been given a score between 1 and 6 with 1 being the lowest and 6 being the highest. The scores for each dimension given by the respondents were averaged to get a composite score for each dimension, to be used as weights for the 6 dimensions. 
The weights assigned are as follows:

\begin{tabular}{lcccccc}
\hline & I & II & III & IV & V & VI \\
\hline Weight & 4.92 & 3.31 & 3.88 & 3.56 & 4.15 & 4.57 \\
\hline
\end{tabular}

MCI for the two banks is calculated as shown below.

Table 6 MCI - foreign banks

\begin{tabular}{lccc}
\hline & Average score & Weight & Weighted score \\
\hline I & 36.76 & 4.92 & 180.8592 \\
II & 28.80 & 3.31 & 95.3280 \\
III & 22.36 & 3.88 & 86.7568 \\
IV & 26.28 & 3.56 & 93.5568 \\
V & 26.32 & 4.15 & 109.2280 \\
VI & 31.28 & 4.57 & 142.9496 \\
\hline Total & & 24.39 & 708.6784 \\
\hline
\end{tabular}

Weighted average $=708.6784 / 24.39=\mathbf{2 9 . 0 6}$

Table 7 MCI - private sector banks

\begin{tabular}{lccc}
\hline & Average score & Weight & Weighted score \\
\hline I & 28.60 & 4.92 & 140.7120 \\
II & 20.20 & 3.31 & 66.8620 \\
III & 13.12 & 3.88 & 50.9056 \\
IV & 17.12 & 3.56 & 60.9472 \\
V & 15.48 & 4.15 & 64.2420 \\
VI & 23.04 & 4.57 & 105.2928 \\
\hline Total & & 24.39 & 488.9616 \\
\hline
\end{tabular}

Weighted average $=488.9616 / 24.39=\mathbf{2 0 . 0 5}$

Table $8 \mathrm{MCI}$ - public sector banks

\begin{tabular}{lccc}
\hline & Average score & Weight & Weighted score \\
\hline I & 17.80 & 4.92 & 87.5760 \\
II & 15.88 & 3.31 & 52.5628 \\
III & 8.52 & 3.88 & 33.0576 \\
IV & 14.48 & 3.56 & 51.5488 \\
V & 16.96 & 4.15 & 70.3840 \\
VI & 20.00 & 4.57 & 91.4000 \\
\hline Total & & 24.39 & 386.5292 \\
\hline
\end{tabular}

Weighted average $=386.5292 / 24.39=\mathbf{1 5 . 8 5}$ 


\section{FINDINGS}

The results of the above analysis show that foreign banks score the highest across all six dimensions. This bank is the leader in 'marketing culture' among the three banks surveyed by a huge margin. Private sector banks follow foreign banks keenly and manage to score more than public sector banks in five out of the six dimensions. The only exception where public sector banks have a score greater than private sector banks are in terms of 'interpersonal relationships'. This reflects that public sector banks' employees consider the feeling of organization treating each employee as more important. The results of comparison of the dimensions for public sector banks are different from the other two banks. The most important dimension rated by public sector banks' respondents is 'interpersonal relationships'. 'Organization' and 'selling task', which are very close to one another, follow interpersonal relationships as highly rated dimensions among the respondents. 'Service quality' has been rated the lowest by public sector banks' respondents. For private sector banks' respondents 'innovativeness' has also emerged as the most important aspect among the six dimensions measuring marketing culture. However, this is followed by 'service quality', which the respondents have found to be as crucial for the success of the bank. 'Organization', 'interpersonal relationships', 'selling task' and 'internal communications' follow the above trends and are all close to each other in terms of significance given by the respondents. Among foreign banks' respondents 'innovativeness' is rated very high showing the attitude of the employees as being fresh and open to ideas of change. This is followed by 'organization' and 'interpersonal relationships', which are considered as more or less equally important.

Thus, the empirical findings upon the seven dimensions of marketing culture indicated that the overall employees' perception of the sales culture in the surveyed banks is moderate. However, the sales culture in the non-Indian banks is stronger than that in the Indian banks. Foreign banks are found to be the leader in terms of 'marketing culture'. They are competitively followed by private sector banks. Three kinds of marketing cultures were found: the strong (the high flyers); the medium (the brisk runners); and the weak (the slow walkers).

\section{LIMITATIONS}

The number of respondents for each category of the banks is 50 in total. The sample size if increased will add more credibility to the results and can bring out fresher insights. Only three banks have been selected for this research, belonging to different categories in the banking industry in India. A higher number of banks can be chosen to better understand the marketing culture in the industry. The respondents for each bank are from two or three branches of the banks in Delhi. A wider distribution of the respondents from different branches and different geographical regions of the country can help in assessing differences in culture among various regional divides.

\section{CONCLUSION}

On a basic level, human systems need some "glue", some central theme or themes around which behavior can coalesce. In the absence of such a thematic element, employees 
cannot know when, toward what, and how to direct their energies. Organizational culture provides this thematic coherence.

The culture of a firm has been found to be important in many other ways. For example, some researchers mention its importance as a form of control of participants. It also might be a critical key used by strategic managers to direct the course of their organizations. Some researchers feel that a firm's culture has as much or more influence on corporate effectiveness as the formal structure of jobs, authority, and technical and financial procedures. Organizational culture affects employees' behavior, a firm's ability to meet their needs and demands, and the way the firm copes with the external environment. It establishes the rationale for "dos and don'ts" of behavior.

The quality of services which are offered to the banks' end customers is dependent on the quality of service provided in the bank's internal work environment. Moreover, the attitude and behavior of employees have a substantial effect on the quality of service provided to the customers. Thus, it has become imperative for top management to administer and rely on marketing culture and effectiveness indexes in their service provider firms. The paper reinforces the importance of sound marketing culture to the Indian banking Sector. The meaning and importance of organization culture, marketing culture and their relevance to firms in general and service firms in particular studied through review of previous researches and manifested empirically. This paper is the first of its kind to study marketing culture dynamics in the context of Indian retail banking industry. The empirical findings upon the seven dimensions of marketing culture indicated that the overall employees' perception of the sales culture in the surveyed banks is moderate. However, the sales culture in the non-Indian banks was stronger than that in the Indian banks.

\section{RECOMMENDATIONS}

The findings of the study have useful implications for policy formulation. Based on the analysis, the following suggestions can be made in order to thrive for a better marketing culture in the banks. Due to high customer interaction in this sector, it is very important for the employees of the bank to believe that their behavior reflects that of the bank. As the opinions formed by customers go a long way in making or breaking relationships, utmost care should be taken to ensure customers are totally satisfied. Employees work area premises should be well organized as an important part of the dimension 'organization'. The employees at foreign banks can do better in this regard. The commitment of top management to provide quality of service management's sharing of financial information with all employees will go a long way in motivating employees to do better, as they would be able to see and assess the results of their enhanced performance.

The executives involved in selling and other front line employees who interact with the customers in various roles are the core team for any bank. Hence it becomes all the more important to involve these front-line executives in standard setting for delivery of better service. The freedom of work and a healthy competitive environment go a long way in enhancing the performance of employees. Therefore, it is emphasized that supervisors have an open door policy. Directing efforts in this regard can help private sector banks scale new heights. 
As far as public sector banks are concerned, systematic, regular measurement and monitoring of employees' performance should be stressed more as it would lead to a competitive environment where employees would definitely strive harder. Over the years, public sector banks enjoying monopoly, have dominated the banking industry but with the ushering in of stiff competition employees' behavior sets banks apart and ahead. For this it is required that the bank starts placing due importance on employees' communication skills. In the shifting paradigms, the bar is being constantly raised. Competition is immense and technology is the key differentiating factor. In such a scenario public sector banks need to be geared up to accept and adapt to changes in practices like development of work force, strong and relevant human resource policies, skill-based training and product knowledge to frontline service providers, etc. As mentioned above, the selling task at public sector banks needs a major revamp. The attitude of the bank is not aggressive. It waits for the customers to reach out to them. It should be fashioned the opposite way. The attitude of employees needs to be changed drastically in this respect. Encouragement of creative approaches to selling is dearly required. Working in a tough competitive environment, Indian banks should focus on enhancing operational efficiency for reducing risk, which ultimately enhances the stability in the banking system (Maji \& Hazarika, 2014).

\section{DIRECTIONS FOR FUTURE RESEARCH}

Servqual (a research model for service quality research) is most valuable when it is used periodically to track service quality trends, and when it is used in conjunction with other forms of service quality measurement. One potential application of Servqual is to determine the relative importance of the five dimensions in influencing customers' overall quality perceptions. It can also help in assessing consumer expectations about and perception of service quality and pinpointing areas requiring managerial attention and actions to improve service quality. Thus, on the overall front of creating and sustaining a marketing culture, the most important aspect of Service Quality can be separately researched. A possible comparison of different or related service industries can also be undertaken, for example, comparison of the retail banking industry and insurance industry. Future studies could also look for the effect of each variable of marketing culture on the service quality of banking firms.

\section{REFERENCES}

AMA (2013). Definition of marketing. Retrieved from: https://www.ama.org/AboutAMA/Pages/Definition-ofMarketing.aspx, Accessed on: 25 March 2018.

Anttila, M., MoËller, K. \& Rajala, A. (1995). Assessing market orientation of high technology companies: A study in the Finnish electrical and electronics industry. In Bergadaa Â.M. (Ed.), Marketing Today and for the 21st Century, Vol. 2, (pp. 1383-1392), 24th EMAC Conference, Paris, 16-19 May.

Arrawatia, R. \& Mishra, A. (2012). Assessment of competition in Indian banking. European Journal of Business and Management, 4 (20), 159-169.

Arrawatia, R., Mishra, A. \& Dawar, V. (2015). Bank competition and efficiency: Empirical evidence from India market. International journal of Law and Management, 57 (3), 217-231.

Baker, M.J. (1974). Marketing: An Introductory Text. London, UK: Macmillan.

Berry, L.L, Hensel, J.S. \& Burke, M.C. (1976). Improving retailer capability for effective consumerism response. Journal of Retailing, 52 (3), 3-14.

Berry, L.L., Bennett, D.R. \& Brown, C.W. (1989). Service Quality: A Profit Strategy for Financial Institutions. Homewood, IL: Dow-Jones Irwin. 
Berry, L.L. (1984), Service marketing is different. In Lovelock, C. (Ed.), Services Marketing: Text, Cases \& Readings, (pp. 29-36), Englewood Cliffs, NJ: Prentice Hall.

Beyer, J.M., \& Trite, H.M. (1987). How an organisation's rites reveal its culture. Organisational Dynamics, 15 (Spring), 5-24

Cadogan, J.W. \& Diamantopoulos, A. (1995). Narver and Slater, Kohli and Jaworski and the market orientation construct: Integration and internationalization. Journal of Strategic Marketing, 3 (1), 41-60.

CAFRAL (2010). Retrieved from: http://www.cafral.org.in/Home.aspx, Accessed on: 11 March 2018.

Deal, T.E. \& Kennedy, A.A. (1982). Corporate Cultures: The Rites and Rituals of Corporate Life, Massachusetts, USA: Addison-Wesley Publishing Company.

Deshpande, R. \& Webster, Frederick E., Jr. (1989). Organizational culture and marketing: Defining the research agenda. Journal of Marketing, 53 (1), 3-15.

Devlin, J. \& Ennew, C. T. (1997). Understanding competitive advantage in retail financial services. International Journal of Bank Marketing, 15 (3), 73-82.

Farley, J.U., Hoenig, S. \& Ismail, Z. (2008). Organizational culture, innovativeness, market orientation and firm performance in South Africa: An interdisciplinary perspective. Journal of South African Business, 9 (1), 59-76.

Gregory, K. (1983). Native view paradigms: Multiple cultures and culture conflicts in organisations. Administrative Science Quarterly, 28(3), 359-376.

Grönroos, C. (1989). Defining marketing: A market-oriented approach. European Journal of Marketing, 23 (1), 52-60.

Gummesson, E. (1987). The new marketing: Developing long-term interactive relationships. Long Range Planning, 20 (4), 10-20.

Gundlach, G.T. (2007). The American Marketing Association's 2004 definition of marketing: Perspectives on its implications for scholarship and the role and responsibility of marketing in society. Journal of Public Policy \& Marketing, 26 (2), 243-250.

Harris, L.C. \& Ogbonna, E. (2002). The unintended consequences of culture interventions: A study of unexpected outcomes. British Journal of Management, 13 (1), 31-49.

Harrison, R. (1972). Understanding your organisation's character. Harvard Business Review, 50 (May-June), 119-128.

Homburg, C. \& Pflesser, C. (2000). A multiple-layer model of market-oriented organizational culture: Measurement issues

Hooley, G.J., Lynch, J.E. \& Shepherd, J. (1990). The marketing concept: Putting the theory into practice. European Journal of Marketing, 24 (9), 7-24.

Jaworski, B.J. \& Kohli, A.K. (1993). Market orientation: antecedents and consequences. Journal of Marketing, $57(3), 53-70$.

Jayaratne, J. \& Strahan, P. (1996). The finance-growth nexus: Evidence from bank branch deregulation. Quarterly Journal of Economics, 3 (3), 639-670.

Kapsis, L. (2012). Competition law and policy for the EU banking sector in a period of increased economic uncertainty. International Journal of Law and Management, 54 (4), 284-301.

Karatepe, O.M., Yavas, U. \& Babakus, E. (2005). Measuring service quality of banks: Scale development and validation. Journal of Retailing and Consumer Services, 12, 373-38.

Kilmann, R.H. \& Saxton, M.J. (1983). The Kibnann-Saxton Culture-Gap Survey, Pittsburgh: Organizational Design Consultants

Kirca, A.H., Jayachandran, S. \& Bearden, W.O. (2005). Market orientation: A meta-analytic review and assessment of its antecedents and impact on performance. Journal of Marketing, 69 (2), 24-41.

Kohli A.K. \& Jaworski, B.J. (1990). Market orientation: The construct, research propositions, and managerial implications. Journal of Marketing, 54 (2), 1-18

Kotler, P. (1977). From sales obsession to marketing effectiveness. Harvard Business Review, 55 (November-December), 67-75.

Kotler, P. (2003). Marketing Management. New Jersey: Prentice Hall.

Kumar, S. \& Gulati, R. (2008). Evaluation of technical efficiency and ranking of public sector banks in India: An analysis from cross-sectional perspective. International Journal of Productivity and Performance Management, 57 (7), 540-568.

Lok, P. \& Crawford, J. (2004). The effect of organisational culture and leadership style on job satisfaction and organisational commitment: A cross-national comparison. Journal of Management Development, 23 (4), 321-338.

Luk, S.T. (1997). An examination of the role of marketing culture in service quality. International Journal of Contemporary Hospitality Management, 9 (1), 13-20. 
Lusch, R.F. (2007). Marketing's evolving identity: Defining our future. Journal of Public Policy \& Marketing, 26 (2), 261-268.

Maji, S.G. \& Hazarika, P. (2014). Competition in the Indian banking sector: A panel data analysis. In Adigal, V.S. \& Mehta, M.C. (Eds.), Changing Finance and Economic Perspective, (pp. 287-296), New Delhi: Bharati Publications.

Maji, S.G. \& Hazarika, P. (2016). Does competition influence the financial soundness of banks? Evidence from the Indian banking sector. Indian Journal of Finance, 10 (10), 27-41.

Maji, S.G., \& Hazarika, P. (2018). Capital regulation, competition and risk taking behaviour of Indian banks in a simultaneous approach. Managerial Finance, 44 (4) 459-477.

Mazur, P.M. (1947). Does distribution cost enough? Fortune, XXXVI (5), 138-9; 192-200.

McKinsey \& Company. (2010). Banking on Multichannel. Research Report, Chicago (IL).

Mohan, R. (2005). Financial sector reforms in India: Policies and performance analysis. Economic and Political Weekly, 40 (12), 1106-1121.

Mohan, R., Khan, M.S. \& Janjua, M.A. (2005). Reforms, Productivity, and Efficiency in Banking: The Indian Experience. The Pakistan Development Review, 44 (4), 505-538.

Narver, J.C. \& Slater, S.F. (1990). The effect of a market orientation on business profitability. Journal of Marketing, 54 (4), 20-35.

Norborn, D., Birley, S., Dunn, M. \& Payne, A. (1990), A four nation study of the relationship between marketing effectiveness, corporate culture, corporate values, and market orientation. Journal of International Business Studies, 21(Third quarter), 451-68.

O'Reilly, P. (2003). Internet banking system: An exploration of contemporary Issues. Journal of Systems and Information Technology, 7 (1/2), 93-110.

O'Reilly, C.A., III. (1989). Corporations, culture, and commitment: Motivation and social control in organizations. California Management Review, 31 (4), 9-25.

Parasuraman, A. (1987). Customer oriented organisational culture: A key to successful services marketing. Journal of Services Marketing, 1 (1), 73-76.

Parasuraman, A., Zeithaml, V.A. \& Berry, L.L. (1988). SERVQUAL: A multiple item scale for measuring consumer perception of service quality. Journal of Retailing, 64 (1), 12-37.

Peters, T.J. \& Waterman, R.H. (1982). In Search of Excellence, New York: Harper and Row.

Schein, E.H. (1985). Organisational Culture and Leadership, San Francisco: Jossey-Bass.

Schneider, B. \& Bowen, D.E. (1985). Employee and customer perceptions of service in banks: Replication and extension. Journal of Applied Psychology, 70, 423-433.

Schneider, B. \& Reichers, A. (1983). On the etiology of climates. Personnel Psychology, 36 (1), 19-39.

Slater, S.F. \& Narver, J.C. (1994). Does competitive environment moderate the market orientation-performance relationship? Journal of Marketing, 58 (1), 46-55.

Smircich, L. (1983). Concepts of culture and organizational analysis. Administrative Science Quarterly, 28 (3), 339-358.

Thompson, M. \& Wildavsky, A. (1986). A cultural theory of information bias in organizations. Journal of Management Studies, 23 (3), 273-286.

Webster, C. (1993). Refinement of the marketing culture scale and the relationship between marketing culture and profitability of a service firm. Journal of Business Research, 26 (2), 111-131.

Webster, C. (1995). Marketing culture and marketing effectiveness in service firms. Journal of Services Marketing, 9 (2), 6-21.

Zeithaml, V.A., Bitner, M.J., \& Gremler, D.D. (2006). Services Marketing: Integrating Customer Focus across the Firm. $4^{\text {th }}$ edition, Singapore: McGraw-Hill.

\section{WEBSITES REFERRED}

www.private sector banksbank.com www.foreign national banks-india.com www.indiainfoline.com Www.statebankofindia.com www.ama.org www.cafral.org 


\section{MARKETINŠKA KULTURA I FINANSIJSKE USLUGE U KONTEKSTU RETAIL BANKARSTVA U INDIJI}

Industrija usluga brzo postaje ključ uspeha nacije i njen značaj u svetskoj ekonomiji je ogroman. U Indiji takođe, nagli razvoj industrije usluga je podstakao rast ekonomije. Industrija usluga je drugačija i stoga postavlja posebne izazove upravljanja. Postoje neke neobične varijable koje utiču na performanse ovih organizacija. Marketinška kultura organizacije je jedan od takvih faktora. Rad se bavi ovom temom u kontekstu bankarskog sektora u Indiji. Nakon liberalizacije, bankarska industrija je postala visoko konkurentna jer se broj bankarskih institucija višestruko povećao. Trenutno u Indiji ima 87 banaka (21 banka u javnom vlasništvu, 21 banka u privatnom vlasništvu i 45 stranih finansijskih posrednika i banaka) koje su međusobna konkurencija. Takođe je primećeno da je jedna od varijabli u nadmetanju banaka ostvarivanje superiorne saradnje sa klijentima, što je moguće kroz zaposlene koji su usmereni na kupce i marketinšku kulturu koja postoji u bankarskoj organizaciji. Marketinška kultura se odnosi na obrazac zajedničkih vrednosti $i$ uverenja koji pomažu pojedincima da razumeju ulogu marketinga i pruže im norme ponašanja u firmi. Marketinška orijentacija i kultura u okviru organizacije predstavljaju najviši imperativ.

Rad je zasnovan na primarnom istraživanju koje je obuhvatilo tri banke koje su odabrane iz svake od gore pomenutih kategorija. Izrađen je upitnik pomoću koga je procenjena marketinška kultura uslužnih banaka. Upitnik koristi 34 stavke kojima se meri šest dimenzija marketinške kulture koje su identifikovali vodeći istraživači. Ovih šest dimenzija čine kvalitet usluge, interna komunikacija, inovativnost, organizacija, međusobni odnosi i zadaci prodaje. U radu je korišćen parametarski pristup za analizu i razumevanje stava zaposlenih u svakoj od banaka po pitanju identifikovanih dimenzija. Takođe su proučavani međusobni odnosi ovih šest dimenzija za svaku od banaka. Svakoj od šest dimenzija je dodeljena težina i odgovori su ocenjeni u skladu sa tim. Rezultati analize jasno pokazuju da strane banke imaju najviši indeks marketinške kulture, a nacionalizovane banke najniži.

Ključne reči: marketinška kultura, kvalitet usluga, interna komunikacija, inovativnost, međuljudski odnosi i zadaci prodaje 